\title{
Corneal Transplant
}

National Cancer Institute

\section{Source}

National Cancer Institute. Corneal Transplant. NCI Thesaurus. Code C50514.

The corneal tissue from a donor. 